\title{
ENTRE O PÚBLICO E O PRIVADO: OS ANDARILHOS NAS CIDADES
}

\section{BETWEEN PUBLIC AND PRIVATE: WALKERS IN THE CITIES}

\section{Henrique Roriz Aarestrup Alves*}

RESUMO: Os romances A fúria do corpo, de João Gilberto Noll e O rei de Havana, de Pedro Juan Gutierrez, apresentam, em suas narrativas, intensas relações entre os corpos de seus personagens e os espaços de suas respectivas cidades, Rio de Janeiro e Havana. Nesses contatos, os corpos funcionam como referência identitária, intermediados por frequentes relações sexuais e diversos tipos de violência. Esse movimento parece encontrar ressonância no incessante perambular pelas cidades, indicando significativos deslocamentos e relativização de fronteiras.

PALAVRAS-CHAVE: erotismo, corpo, andarilho, cidade.

ABSTRACT: The novels A fúria do Corpo, by João Gilberto Noll, and O rei de Havana, by Pedro Juan Gutierrez, show an intense relation between the bodies of the characters and the spaces around their respective cities, Rio de Janeiro and Havana. In these contacts, the bodies work as an identity reference, intermediated by frequent sexual relationship and various kinds of violence. This movement seems to find resonance in the incessant wandering around the two cities, which indicates meaningful displacement and relativizes the bounderies.

KEY-WORDS: eroticism, body, wanderer, city.

\footnotetext{
* Professor efetivo de Literaturas de Língua Portuguesa da Universidade do Estado do Mato Grosso - UNEMAT -, Campus de Sinop; Doutor em Letras pela PUC-Minas; e-mail: hraalves@hotmail.com
} 

"O único roteiro é o corpo. O corpo."

João Gilberto Noll

A esfera pública, na condição de instância que discute as normas gerenciadoras do funcionamento da própria vida social no âmbito "privado", influencia diretamente nas relações entre corpo e cidade. Ao delimitar espaços específicos para a atuação do indivíduo, as sociedades tentam organizar suas ações e comportamentos, de acordo com classificações que os consideram como públicos ou privados. Em sistemas capitalistas modernos, a esfera do poder público, representado pelo Estado, trataria de questões coletivas em instituições sociais criadas para esse fim, enquanto o espaço privado estaria situado nas relações industriais e comerciais de trabalho, e também na intimidade da família burguesa e suas posses. Habermas afirma que "a compreensão que o tirocínio público tem de si mesmo é dirigido especificamente por tais experiências privadas que se originam da subjetividade, em relação ao público, na esfera íntima da pequena-família" (2003: 43). O setor público estaria, em princípio, intimamente ligado ao privado, mas separado por fronteiras determinadas pelas normas que gerenciam suas instituições em suas especificidades sociais. Nesse sentido, a esfera pública funcionaria como uma dimensão negociadora entre o poder público e os interesses do capital privado, formulando, então, as regras gerenciadoras não só do funcionamento da sociedade civil, mas do âmbito social como um todo. 
Karl Marx já criticava essa esfera pública burguesa, considerando que assumiria uma condição de classe em seu processo de formação, o que deveria ser combatido pela inclusão das outras no espaço público: na medida em que essas classes não seriam consideradas proprietárias, não haveria o interesse em manter a sociedade civil enquanto esfera privada, ocasionando uma mudança estrutural da esfera pública burguesa. Dessa forma, a esfera pública assumiria um caráter mais democrático ao deliberar e administrar publicamente a vida social, tendo em vista a socialização dos meios de produção.

De qualquer maneira, nesse processo de estabelecer as fronteiras entre o público e o privado, tanto as sociedades capitalistas quanto as socialistas instituem seus significados simbólicos ao "imprimi-los" nas dimensões corporais e espaciais dos indivíduos e das cidades, dando sentido a eles. Aliás, ao privilegiarem o campo do público em detrimento do privado, as sociedades socialistas apresentariam algumas particularidades na demarcação de corpos e cidades, em relação às sociedades capitalistas. De qualquer maneira, os corpos e os ambientes urbanos adquirem sentidos diante das próprias relações firmadas entre essas instâncias, na medida em que são formatados para serem reconhecidos em sua materialidade e "corporeidade" social.

Na modernidade capitalista, a moralburguesae suas práticas encontravam respaldo na própria ciência iluminista, a qual sempre procurou racionalizar o funcionamento do corpo no intuito de classificá-lo e, consequentemente, direcioná-lo para a dinâmica do trabalho e da circulação de mercadorias nos ambientes urbanos. Tendo em vista as relações entre corpo e cidade, Richard Sennett, em sua obra intitulada Carne e pedra, reflete sobre a influência das descobertas científicas, como a da circulação sanguínea do corpo humano, na reestruturação sofrida pelas cidades, apontando para a necessidade de maior espaço para a circulação dos transeuntes:

Construtores e reformadores passaram a dar mais ênfase a tudo que facilitasse a liberdade do trânsito das pessoas e seu consumo de oxigênio, imaginando uma cidade de artérias e veias contínuas, através das quais os habitantes pudessem se transportar tais quais hemácias e leucócitos no plasma saudável (1997: 214).

Dessa maneira, o teórico indica as profundas transformações, operadas no "corpo" da cidade, a partir da metáfora da circulação sanguínea e dos movimentos respiratórios. Contraditoriamente, esse projeto moderno de desenvolvimento das vias de circulação para promover a "saúde" da 
própria cidade será contaminado pela heterogeneidade cultural, pelo desequilíbrio social e descontrole arquitetural do próprio "corpo" urbano, que se vê descentrado e fragmentado em sua pretensão de estabilidade. Dessa forma, os habitantes em deslocamento nesse "sistema circulatório", "tais quais hemácias e leucócitos no plasma saudável", se veem inseridos muito mais em um contexto de septicemia do que de assepsia, na medida em que os projetos higienistas fracassam ao perderem o controle sobre o funcionamento e estruturação dos espaços urbanos. A modernidade de cunho positivista, centrada na "ordem e progresso", mostrar-se-ia, pois, comprometida em suas próprias pretensões civilizatórias ao caminhar para a desordem e o retrocesso de suas propostas. Essa "marcha" da modernidade rumaria para os contextos mais conturbados da pós-modernidade, os quais evidenciariam, definitivamente, a impossibilidade de se maquiar suas contradições. Nesse processo, o centro homogêneo das cidades esfacelase diante do deslocamento provocado pelas influências de outros espaços, muitas vezes periféricos, que se impõem como tópicos. Dessa maneira, o sujeito pós-moderno, ao fazer interagir seus corpos com os espaços citadinos, dilui e fragmenta a nitidez de suas diversas fronteiras, inclusive a de sua identidade, a qual se mostra extremamente fluida e instável. Sendo assim, os indivíduos inseridos nas sociedades contemporâneas sofrem um processo de constante descentramento, e se veem forçados a redimensionarem a percepção de suas identidades, dos espaços urbanos, e de seus próprios corpos.

Esses deslocamentos diversos têm relação direta com a atual crise de instituições sociais e sua "(in)capacidade" de gerenciar a relação entre corpos e ambientes urbanos. Consequentemente, a delimitação dos espaços específicos para a atuação do indivíduo mostra-se comprometida em sua pretensão de estabelecer as fronteiras entre o público e o privado, em consonância com negociações inerentes à esfera pública. Em sociedades capitalistas, o processo de universalização dos valores do capital parece ter sido levado ao extremo, pois se percebe uma tendência à invasão do espaço público pelo privado, na medida em que o poder público incorpora interesses particulares de determinados grupos privados ao invés de fiscalizá-los em nome da coletividade. Na prática das relações sociais, bens públicos são apropriados por interesses particulares, espaços e objetos privados são tomados ou utilizados como se fossem públicos. Nesse contexto de inversões de fronteiras, a esfera pública minimiza seu caráter de embate, já que tanto o Estado quanto os donos do capital convergem 
seus interesses e ações para o próprio capital como o valor maior. A opinião pública também se mostra envolvida por essas confluências, na medida em que os conflitos são banalizados e reflexões críticas se tornam controladas por um turbilhão de discursos que apenas tentam camuflar o fato de que as sociedades pós-modernas se alimentam de suas próprias contradições.

Na narrativa de $A$ fúria do corpo, de João Gilberto Noll, esse processo de deslocamento de fronteiras entre o público e o privado insere-se no conjunto de inversões diversas realizadas pelos personagens, que levam a um grau extremo o processo de se misturarem às misérias dos ambientes citadinos, chegando, consequentemente, ao limiar do desmanche de seus corpos. No texto, a cidade do Rio de Janeiro é apresentada através de frequentes visitas a diferentes espaços urbanos, como as ruas de Copacabana e outros bairros, o centro, a favela, etc. Ao circular, o narrador-personagem se depara com lugares e situações que interagem intensamente com seu corpo, como os morros cheios de leprosos, armas e drogas; hospitais e enfermarias; apartamentos conjugados; abrigos, boates infernais, cinemas, calçadas e locais de prostituição. Nesse perambular, corpos e espaços urbanos diluem suas fronteiras ao tornarem miscíveis suas degradações, fragmentações e mazelas, desconsiderando, inclusive, as demarcações simbólicas que separam público de privado. Se as ruas e praças da cidade carioca podem ser consideradas como pertencentes ao poder público, servindo para a sociedade civil estabelecer relações sociais específicas, como as comerciais e de trabalho, ao misturarem seus corpos às degradações e fazerem sexo nesses espaços, os personagens problematizam as instituições em suas funções de demarcar a sociedade e, consequentemente, de separar as instâncias pública e privada.

Uma passagem do texto de Noll pode metaforizar algumas dessas inversões que ocorrem nas cidades contemporâneas, assim como suas crises institucionais. Na cena, as vias de circulação dos moradores do morro servem tanto para a satisfação das necessidades fisiológicas do narradorprotagonista quanto para a relação sexual de um casal de leprosos. Nesse contexto, a exposição de relações íntimas entre corpos subverte normas instituídas socialmente, deslocando fronteiras:

começo a mijar e vejo um grito vindo de baixo dois leprosos um em cima do outro e eu tava mijando em cima deles o debaixo devia ser mulher porque tinha umas sobras pelancudas onde outrora devia ser o seio o de cima vinha uma bunda carcomida por crateras e os dois olharam pro meu pau e riram um riso doido e o debaixo que deveria ser mulher pediu que mijasse mais [...]. (1981: 52). 
A cidade do Rio de Janeiro encontra-se inserida no contexto capitalista das sociedades ocidentais modernas e, portanto, as relações entre público e privado obedeceriam às determinações de uma "esfera pública" de origem burguesa. Nesse contexto, à instância privada pertenceriam práticas pessoais definidas, como higiene corporal, relações sexuais, além de outros comportamentos domésticos mais subjetivos e realizados no âmbito das residências particulares. Sendo assim, os personagens da narrativa de Noll subverteriam as relações entre público e privado ao fazerem sexo nas ruas da cidade e misturarem seus corpos com os espaços urbanos degradados, colocando em questão os padrões de comportamento instituídos na cidade carioca contemporânea. A rua, espaço público determinado para o trânsito das pessoas e relações sociais específicas, é ocupada pelos personagens como se fosse propriedade privada, ou seja, pertencente à esfera íntima de práticas pessoais, ao passo que seus corpos, ao executarem atividades típicas da vida privada, como o sexo, tornam-se públicos. Essa inversão parece evidenciar a desestabilização que sofrem as próprias instituições no contexto pós-moderno da sociedade brasileira, na medida em que se encontram comprometidas em suas funções de gerenciar a vida social de acordo com suas normas e demarcações de fronteiras diversas. Dessa forma, o controle dos corpos pelas instituições sociais é abolido, mesmo que em regiões periféricas da cidade, como no espaço da favela do texto de Noll. Nesse processo, ao exteriorizar e misturar seus fluidos internos, como urina e sangue, os corpos se superficializam e tornam explícitas suas próprias entranhas, subvertendo não só a compartimentação dos espaços urbanos, mas também dos orgânicos, na medida em que apresentam pouco nítidas as divisas que permitem identificar e diferenciar seus gêneros e partes anatômicas. É interessante observar que os elementos intersticiais do corpo, como orifícios, excrementos, secreções e demais líquidos orgânicos representariam a possibilidade de invasão de um compartimento corporal por outro, como se a mistura entre eles significassem algum perigo em potencial. Materiais produzidos pelo corpo, como saliva, catarro, pus e sangue, por exemplo, por apresentarem consistência "pastosa", fluida ou de contornos não fixos, podem significar um incômodo, um mal-estar simbólico causado, justamente, pela dificuldade de controle sobre eles. Nesse sentido, esses componentes do corpo devem ocupar espaços específicos não somente devido ao próprio funcionamento orgânico, mas principalmente por questões culturais, tornando-se alvo da organização social através de práticas higiênicas que funcionam muito mais como "rituais" de limpeza. 
Dessa forma, a dimensão "natural" do corpo tende a ser culturalizada, adquirindo sentido aos olhos da sociedade. De acordo com José Carlos Rodrigues, em Tabu do corpo, o sentimento de nojo significaria a própria subversão da ordem social "impressa" no corpo:

A reação de nojo é uma reação de respeito pelas convenções que classificam e separam. Assim como o ato de purificar é um ato de retirar as manchas que borram as linhas de demarcação dos limites de cada categoria - porque é necessário haver separação para haver comunicação e haver sentido para a poluição ter sentido. Uma coisa nojenta é sempre uma coisa que cruza indevidamente uma linha demarcatória, estabelecendo-se em um lugar impróprio e deslocado do sistema de ordenação. A reação do nojo é uma reação de proteção contra a transgressão da ordem (2006: 125).

Dessa maneira, a passagem do texto de Noll transgride a organização social que pretende delimitar o corpo e os espaços urbanos. Importante observar que a própria favela em que se passa a cena poderia ser considerada como uma parte do "corpo" urbano sobre a qual a sociedade não conseguiria exercer pleno controle. Com o processo de relativização de fronteiras entre "centro" e "periferia" que ocorre nas cidades pós-modernas, muitas vezes alguns grupos considerados como "intersticiais" são vistos como portadores de elementos poluígenos capazes de "contaminar" o tecido social, pois representariam uma ameaça de "mistura" ao não mais se fixarem em espaços urbanos socialmente determinados para eles, como a favela ou o subúrbio. De qualquer maneira, o espaço da favela, na narrativa, remete à ideia de total falta de controle das regras instituídas sobre os corpos e os territórios da cidade. Na passagem, os leprosos estabelecem contatos físicos com a urina do personagem narrador sem esboçar o menor sinal de nojo ou aversão. Aliás, eles riem e pedem que o narrador urine mais em cima deles, subvertendo as normas sociais que determinam locais apropriados para a satisfação das necessidades fisiológicas e sexuais. O riso expressa o ato transgressivo em si, pois é provocado, de forma consciente, pela sensação de desobediência à regra enquanto referencial de conduta. Além disso, a reação dos leprosos indicaria certo nível de satisfação ao misturarem seus corpos deformados com urina, apontando, assim, para mistura de elementos orgânicos e anatômicos como componentes de suas corporeidades comprometidas pela desintegração. Sendo assim, a lepra faz-se metáfora da perda de limites corporais, que se confundem na deformação dos membros e suas extremidades. Esse apagamento de 
limites entre corpos é levado a um grau extremo nessa passagem do texto de Noll, pois, misturados às suas fronteiras, encontram-se lama, sangue, sêmen e urina, além da própria deformidade, que acentua ainda mais a indistinção entre eles. A falta de controle sobre esses elementos corporais que deveriam estar separados e retidos em seus devidos lugares, de acordo com a ordem estabelecida, parece evidenciar, metaforicamente, a falência e a fragilidade das instituições reguladoras da vida social. Nesse sentido, o caráter transgressor da ação dos personagens consistiria, principalmente, em remeter as regras sociais para a instância do arbitrário ao deslocar seus corpos para além dos dispositivos de coerção. A respeito do controle social sobre o corpo, José Carlos Rodrigues observa que:

Temos aí, em estado prático, um sistema de classificação de pessoas e de comportamentos em 'íntimos', 'privados', 'públicos', 'sociais', 'coletivos' etc., bem como uma classificação de situações em que se podem observar estes comportamentos, situações passíveis de determinar diretamente a natureza do comportamento - especialmente nesse terreno, já que muitos comportamentos são realizáveis apenas em público, alguns são nojentos no contexto doméstico, outros não o são no contexto erótico e assim por diante... (2006: 139).

Ao analisar os processos de afastamento e/ou aproximação de corpos em determinadas circunstâncias, o teórico ressalta a necessidade cultural de classificação de comportamentos e atividades como forma de afirmar a legitimidade das próprias instituições e suas organizações reguladoras da vida social. Entretanto, os leprosos da passagem de Noll, com suas "crateras corporais" e extremidades carcomidas, parecem funcionar como uma alegoria da sociedade brasileira e suas instituições, cujas fissuras e desgastes exibem a desintegração e a incapacidade de gerenciamento por trás de sua pretensão de funcionalidade. Nesse processo, os sistemas de controle que procuram rotular "a natureza do comportamento" são desvinculados dos corpos dos personagens e espaços da favela, os quais parecem ser remetidos a uma época pré-moderna de civilização em que tudo se misturava e apresentava outros significados. Nesse contexto, a modernidade seria questionada, pois as diferenças entre os âmbitos público e privado que organizam os sentidos do mundo civilizado são suprimidas pela impossibilidade de se maquiar o descontrole sobre os impulsos naturais inerentes à integralidade dos corpos, os quais se tornam explícitos na narrativa. Nesse momento, a pretensão iluminista de racionalizar totalmente corpos e cidades via discurso científico entra em crise nos contextos incertos da modernidade tardia. 
A transgressão desses limites, no texto de Noll, ressignifica a sociedade brasileira ao evidenciar a existência de inexoráveis contradições em seu projeto de civilização moderna. Para além desse contexto, o personagem narrador e Afrodite, em suas interações corporais e espaciais, indicam a possibilidade de existência em um movimento erótico que suplanta a cultura e suas normas comportamentais. Freud afirma que "a cultura tem sido conquistada por obra da renúncia à satisfação das pulsões e exige de todo novo indivíduo a mesma renúncia” (apud MAURANO, 1999: 69). Entretanto, na narrativa de Noll, as pulsões dos personagens direcionariam a libido para a supressão dos interditos sociais, que se mostram fracassados em sua função de reprimir os desejos primordiais de forma eficiente. Dessa maneira, os impulsos sexuais ganham em carga erótica ao se voltarem basicamente para os corpos, impulsionando os andarilhos em suas ações e movimentações pelos espaços urbanos. Nesse processo, a própria civilização seria questionada no jogo pulsional que desloca o desejo não para a construção cultural, e sim para o vazio contido na própria incapacidade de satisfação do sujeito em seus instintos primordiais. Nesse espaço psíquico, Eros e Thanatos digladiam-se tragicamente, ou, mais do que isso, anulam-se, levando o desejo sexual ao limite da desintegração dos corpos, os quais estendem seus processos de mistura de compartimentos para a organização simbólica da sociedade, problematizando-a. Dessa maneira, a repressão aos instintos realizada pela cultura encontraria uma reação violenta do sujeito, na narrativa de Noll, na forma de pulsão erótica, já que, de acordo com Freud, "não se faz isso impunemente" (1974: 118). Sendo assim, o próprio erotismo poderia ser considerado como reação e consequência dessa intervenção repressiva às pulsões, fazendo sentido, somente, mediante a cultura. Nesse contexto, não haveria um esvaziamento da cultura no sentido de nadificá-la, e sim uma tentativa de superação através dos excessos do corpo e dela própria, pois, afinal de contas, é o narrador personagem que fala na maior parte da narrativa, fazendo uso, assim, da linguagem enquanto manifestação cultural, ainda que seja para expressar suas experiências eróticas.

Diferentemente do texto de Noll, a narrativa de O rei de Havana, de Pedro Juan Gutiérrez, explicita não a transgressão erótica dos limites simbólicos, mas seu próprio esvaziamento quando se inserem nos significados sociais cubanos. A narrativa de Gutiérrez situa-se na década de 1990, a partir do chamado "período especial" em Cuba, estendendo-se para 
alguns anos subsequentes em que reformas do governo foram implantadas. De qualquer maneira, o romance manifesta os reflexos dessa época de crises graves da sociedade cubana, ocorridas após o rompimento dos laços com a União Soviética. $\mathrm{O}$ texto alude a esses problemas ao apresentar o processo de degradação extrema da ilha e seu sistema socialista, com suas instituições públicas, edificações e demais espaços urbanos em ruínas. Dessa maneira, a "modernidade socialista" de Cuba mostrar-se-ia falida em sua pretensão de estender seus ditos benefícios a todos os setores da sociedade, desenvolvendo-a de forma igualitária. Uma das diferenças do sistema socialista em relação aos meios de produção capitalista consistia em abolir sua condição de propriedade privada e os processos de alienação a ele inerente, priorizando a igualdade social e os interesses coletivos da população. Nesses moldes, Cuba pretendeu estruturar uma sociedade sem classes, cuja "esfera pública" era representada, basicamente, pelo Estado, o qual estendeu suas fronteiras para praticamente todas as instituições sociais. Porém, a incapacidade do poder público em gerenciar comportamentos e demarcar espaços urbanos torna-se nítida na narrativa, indicando, assim, uma diluição das fronteiras entre as instâncias pública e privada.

Nesse contexto, ocorre a exposição de pormenores das relações sexuais de forma detalhada, colocando em questão essas dimensões sociais da sociedade cubana:

Atravessaram o parque Maceo. Sentaram-se em cima do muro. Ela se recostou numa coluna e abriu as pernas. Estava com uma saia larga que chegava aos tornozelos. Rey se acomodou de frente, tirou o bicho prá fora, que ficou duro assim que sentiu o cheiro de buceta fedida e ácida de Magda, e ali mesmo copularam freneticamente, dando mordidas no pescoço um do outro. Claro que automaticamente apareceram os voyeurs de sempre do parque Maceo. Desembainharam e tocaram suas punhetas feito loucos desfrutando o frenesi alheio. (2001: 59).

Faz-se interessante observar que, nesse momento histórico, ainda prevalece a dimensão pública em detrimento da privada na sociedade cubana. Dessa maneira, tanto as ruas e praças de Havana quanto seus prédios abandonados constituem o espaço público gerenciado pelo Estado. Na narrativa, os locais da cidade ocupados por Reynaldo, Magda e demais personagens poderiam ser considerados como pertencentes ao poder público, apesar de se encontrarem completamente abandonados por ele. 
Aliás, como ainda existe no país uma união entre Estado e sociedade civil, a pequena abertura dada à propriedade privada permanece controlada fortemente pelo governo. Nesse sentido, poder-se-ia dizer que a prevalência da instância pública, em Cuba, exerceria grande influência nas relações sociais, no sentido de tratarem, prioritariamente, de interesses coletivos e inerentes à maioria da população. É claro que existem normas sociais cubanas que consideram particulares certas práticas da vida pessoal dos indivíduos, como higiene pessoal e sexo, mesmo porque, a herança cultural europeia e americana de séculos anteriores não seria totalmente anulada, e sim apenas redimensionada nas décadas de sistema socialista. Nesse sentido, a sociedade cubana também situaria a prática sexual no setor particular do comportamento e, portanto, separada de outras relações sociais.

Na narrativa de Gutiérrez, entretanto, a fraca presença da esfera pública exerce certa influência nas interações de cunho mais "íntimo", como o sexo, que se torna radicalmente público em alguns espaços da cidade de Havana. Como as normas sociais se encontram suprimidas nesses ambientes, não por transgressão de sua existência, mas pelo apagamento de sua presença, os corpos e suas interações sexuais situam-se em um espaço "público" em processo de permanente desintegração não só física, mas também simbólica. Nesse contexto, Rey e Magda levam esse processo ao extremo, pois se relacionam sexualmente de maneira indiferenciada, como se o parque Maceo e as instalações degradadas do prédio abandonado que ocupam formassem um único espaço sem demarcação de fronteiras entre público e privado. A despeito da existência de qualquer demarcação simbólica entre esses limites, tanto os espaços urbanos quanto as práticas sexuais entram em consonância em seus aspectos esvaziados de elementos eróticos. Qualquer caráter individual que as relações sexuais possam ter é diluído e esvaziado no texto, pois estas são praticadas em espaço "público" e, portanto, aberto a qualquer interferência de outrem. Na ausência dessas instâncias referenciais, os personagens mantêm o mesmo comportamento considerado "privado" no espaço "público" do parque, sem esboçarem qualquer reação que possa diferenciar as relações sexuais realizadas nos ambientes fechados do prédio por eles ocupado. Na passagem do texto, os "voyeurs de sempre" que ali se masturbam reforçam essa ideia de apagamento ou esvaziamento das fronteiras entre público e privado, como se essas práticas fossem uma rotina pouco ou nada clandestina, pois não parecem estar prestes a serem repreendidas, a qualquer momento, por dispositivos de coerção. A passagem seguinte reforça ainda mais esse processo: 
Que dia será hoje? Olhou em volta. A uns metros, um negro tocava uma punheta olhando um casal que trepava um pouco mais adiante, sentado de frente em cima do amplo muro do Malecón, se mexendo ritmicamente, e o negro, absorto no espetáculo, se masturbando no mesmo ritmo. Rey não teve dúvida.

- Psiu, psiu, ô, ô... psiu, ô, ô...

O sujeito se sentiu surpreendido. Assustado, guardou o falo precipitadamente e com certeza perdeu a ereção num segundo, pensando que algum policial podia tê-lo apanhado em fraganti-manus falus na via pública. Olhou dissimuladamente para o lado de onde chamavam. Aí, Rey lhe perguntou:

- Que dia é hoje, cara?

- Ahn?

- Que dia é hoje, cara?

- Ahn, do que? O que você está falando?

- A data, a data. Que dia é hoje?

- Ah, não... porra, cara... Não sei, não sei... porra, você acabou comigo (2001: 117-18).

Indiferente ao fato de os personagens estarem em atividade sexual, Reynaldo dirige-se ao negro que estava se masturbando, como se não houvesse qualquer separação entre essa prática e as outras feitas em público, durante as relações sociais rotineiras. Nesse momento, fica claro que o adolescente não estabelece nenhuma distinção entre um comportamento tido como íntimo e "privado" daqueles realizados no âmbito das relações sociais públicas, como perguntar a data ou as horas a alguém, por exemplo. É evidente que Reynaldo codifica as ações sexuais dos personagens como tais, mas não as considera pertencentes a uma dimensão particular, fechada, especial e erotizada, e sim banais, abertas e passíveis de interrupções alheias, como a que efetua. Já o outro personagem reage como se alguma autoridade representante do poder público, como a polícia, estivesse abordandoo, restabelecendo, nesse instante, as fronteiras entre público e privado, permitido e proibido, íntimo e explícito. Ao perder a ereção, o personagem ilustra a incompatibilidade que deveria existir entre a prática sexual e o ato social de comunicar-se publica e discursivamente face a face com alguém estranho. Todavia, essas fronteiras estavam suspensas até o momento em que Rey realiza tal abordagem, ou seja, o abandono dos espaços urbanos pelo poder público torna-as esvaziadas de seus sentidos simbólicos capazes 
de regular a vida em sociedade e impor suas normas de convivência instituídas, como as que não permitem o sexo em vias públicas. Nesse sentido, as instituições públicas de Cuba, que tentam regular as práticas "privadas", como as sexuais, mostrar-se-iam comprometidas e, portanto, com suas codificações suspensas, banalizadas, nadificadas e em processo de tanatomorfose, como o próprio personagem Reynaldo, em sintonia com o poder público ausente. Dessa maneira, tanto o espaço público quanto o "privado" submetido a ele se tornam desintegrados, ilustrando, metaforicamente, Cuba e seu "Estado" de decomposição.

Como esses referenciais limítrofes se mostram comprometidos no texto, eles se apresentariam muito mais esvaziados do que subvertidos ou transgredidos. Os movimentos automatizados dos personagens em suas atividades sexuais indicariam um comportamento muito menos erotizado que robotizado, organicamente pré-programado e demasiadamente previsível. Nesse contexto, a vida sexual - e também a social - tornam-se desguarnecidas de sentidos e, portando, culturalmente vazias. As frenéticas e repetidas interações sexuais em público reforçam sua banalização, chegando ao nível do acultural e do animalizado, já que esvaecidas são as fronteiras simbólicas que delimitam o gerenciamento da sociedade e suas regras institucionais. Ao invés de o espaço do parque transformarse em "privado" pelas atividades sexuais dos personagens, e a intimidade desses atos tornar-se "pública", por ocorrer nesse ambiente aberto, ambas as instâncias parecem se esvair através de seus processos de apagamento nos corpos "urbanos" e "humanos", organicamente, não doutrinados.

Essa questão pode ser considerada como um forte indicativo do comprometimento não só da sociedade e seu sistema de ordenação, mas também das tensões pulsionais entre Eros e Thanatos, responsáveis pelo advento da cultura. Se não há, na narrativa, muitos interditos a serem transgredidos, como uma forma de direcionar o desejo e formatar os impulsos sexuais, então eles fluiriam de forma animalizada e, portanto, acultural, já que não seriam, simbolicamente, intermediados ou reprimidos. Nesse contexto, Eros perderia sua capacidade de mobilizar o indivíduo em sociedade, assim como Thanatos não mais funcionaria como uma força pulsional redimensionadora do desejo. $\mathrm{O}$ resultado desse processo poderia ser observado no personagem Reynaldo, em sua postura indiferente e inerte de lidar com o mundo, com o "outro" e consigo próprio. Já que se mostra evidente na narrativa o comprometimento do desejo e, consequentemente, da tensão pulsional promotora de criações culturais e sexo erotizado, 
resta ao adolescente apenas perambular pelas ruas de Havana de maneira programada para fazer sexo como um "animal" permanentemente no "cio", deixando desintegrar seu corpo e identidade, passivamente, até seu desaparecimento completo.

Em suas interações e perambulações, Reynaldo e Magda descompartimentam não só qualquer tentativa de separação e delimitação dos espaços físicos da cidade como também das instituições sociais, as quais são esvaziadas, simbolicamente, nesse processo. Dessa forma, essas misturas entre corpos e espaços urbanos degradados contaminam a própria cultura em sua função de significar a realidade, pois também se encontra em estado paulatino de desmanche. Nesse sentido, Reynaldo e Magda situam-se no mesmo nível das ruínas do edifício onde moram, na medida em que seus corpos, desidratados e desestruturados, refletem a precária infraestrutura do espaço que habitam, como a falta de água, gás e eletricidade. Extenuados e desgastados, os corpos parecem chegar ao limite da desintegração, assim como o prédio em desmoronamento, o que dilui ainda mais as fronteiras entre eles:

Nenhum dos dois se incomodava com a sujeira do outro. Ela tinha uma xota um pouco ácida e a bunda cheirando a merda. Ele tinha uma nata branca e fedida entre a cabeça do pau e a pele que a rodeava. Ambos cheiravam bodum nas axilas, a rato morto nos pés, e suavam. Tudo isso os excitava. Quando não agüentaram mais foi porque estavam extenuados, desidratados, e anoitecia. Ela e os outros viviam ali ilegalmente porque o edifício podia desmoronar a qualquer momento. Portanto, não tinha água, nem gás, nem eletricidade (2001: 55).

Os corpos encontram-se ligados por suas próprias ruínas que também entram em consonância com os escombros de seus respectivos espaços, apresentando, metonímica e alegoricamente, as entranhas da sociedade cubana em processo de desmanche. Esse descentramento e fragmentação de corpos e espaços, além da degradação que caracteriza suas fronteiras, fazem-se metáfora da própria dinâmica urbana da cidade, que deixa emergir, através de suas fissuras "corporais", os espaços de submundos que se horizontalizam e se impõem na narrativa, trazendo à tona a impossibilidade de se maquiar a falência do projeto revolucionário que pretendia organizar o ambiente citadino, de acordo com os conceitos de "modernidade" preconizados pelo sistema socialista de Cuba. Dessa maneira, os contatos estabelecidos entre lama, sujeira, sangue, sêmen, urina, suores e sexo 
parecem formar uma "massa composta" que dilui qualquer pretensão de se fixar dimensões espaciais e corporais. Nesse "caos disforme", onde degradações e secreções se misturam, emergem simulacros estilhaçados de corpos e de cidade com formações diferenciadas, comprometendo, assim, os espaços urbanos em suas funções institucionalizadas, assim como os corpos que neles e com eles interagem. O processo intenso de "trituração" dos ambientes de Havana e dos corpos remete à ideia de "pulverização" de seus materiais físicos e simbólicos, reduzindo-os a minúsculas "partes" misturadas e indistintas no todo significacional, perdendo o sentido, assim, em "mortes" nadificantes. Nesse sentido, se não há embate entre "pulsão de vida" e "pulsão de morte", não existiria desejo nem em nível destrutivo, pois os corpos, os espaços urbanos e seus significados simbólicos desintegramse por forças de circunstâncias, e não pela interferência dos personagens enquanto sujeitos portadores de impulsos e sentidos de busca. Dessa forma, não haveria, na destruição paulatina da cidade e dos personagens Reynaldo e Magda, a possibilidade de renovação da vida simbólica pelo viés do desejo de vivenciar, erótica e profundamente, a sujeira e as misérias degradantes, como ocorre na narrativa de Noll.

Nas desestabilizadoras "misturas" de corpos e ambientes citadinos degradados, os personagens de A fúria do corpo obedecem, de forma erotizada, a seus impulsos de acordo com suas necessidades fisiológicas e sexuais, colocando em xeque as regras socialmente instituídas para controlálos nos espaços urbanos. Esse processo, porém, ocorreria no contexto institucionalizado da sociedade capitalista brasileira, o que indicaria a possível presença, mesmo que fragilizada, das regras e suas fronteiras de separação entre o público e o privado. Na narrativa, não se percebe a prevalência da prática sexual generalizada, em público e disseminada em parte da população nos ambientes urbanos, como acontece no texto cubano, com seus "voyeurs" e demais frequentadores assíduos de praças e ruas para praticar o sexo. Basta iniciarem uma relação sexual em alguma parte da cidade de Havana para vários observadores aparecerem e se masturbarem, indicando, assim, a suspensão das regras sociais, enquanto, no texto nolliano, as interações sexuais em público são realizadas muito mais pelo personagem narrador e Afrodite do que por outros personagens ou observadores. Os curiosos que por vezes presenciam essas cenas não realizam atividade sexual, funcionando mais como uma referência às regras transgredidas que gerem o mundo exterior, assim como a polícia e sirenes diversas, que indicam a presença institucional do poder público na narrativa: 
[...] e estava ali o mendigo deitado na calçada com a braguilha aberta e um caralho enorme adormecido, paro, me inclino, chamo o mendigo com um acorda companheiro, [...] me viro de costas com a bunda arrebitada e peço que ele me coma o cu, por me comer o cu pago mais três copos de cana, molho o pau do mendigo com meu cuspe e molho o meu cu, o maior caralho do mundo me penetra me penetra me penetra, o mendigo geme na esperança das mil doses de cachaça e me esporreia em litros o cu e caio espatifado entre ferros velhos, $[\ldots]$.

Amanheceu com as moscas voejando e pousando sobre a sarna do meu corpo nu, [...] às vezes de alguma janela das redondezas um olhar ou outro me observava assustado, eu ali de bruços, nu, com a bunda pro céu, a cara contra a terra dura, [...] um olhar ou outro me observando lá de uma janela, de repente sirenes intermináveis de bombeiros misturando-se a sirenes de ambulância e da polícia, a Cidade entrava em combustão espontânea [...]. (1981: 129, 130-1).

Nessa passagem, percebe-se o deslocamento entre as instâncias pública e privada, pois as interações sexuais não se mostram generalizadas, e sim localizadas nos personagens e em determinado espaço público urbano. Dessa forma, as fronteiras que demarcam o território do público encontram-se no espaço da calçada e do terreno que, por ser baldio, afasta-se da condição de propriedade privada, ao mesmo tempo em que se aproxima de uma instância pública ao se tornar passível de ser acessado, mesmo que só pelo olhar. Nesse contexto, os personagens praticam atos considerados íntimos e particulares em um ambiente público, utilizado como se fosse privado. Essas fronteiras e seus deslocamentos são reforçados pela presença dos olhares anônimos de curiosos assustados, além das sirenes de bombeiros e polícia, representantes do Estado. Se não houvesse transgressão, como na narrativa de Gutiérrez, esses olhares não seriam "assustados”, nem haveria a indicação da existência de demarcações simbólicas nos espaços urbanos, "anunciada", sonora e publicamente, pelos dispositivos de controle do poder público. Nessas inversões entre público e privado, seus limites são transgredidos, mas não esvaziados de significados. A interação sexual entre o mendigo e o narrador mistura secreções, sujeira, lixo e corpos, formando uma "combinação" indiferenciada de matéria degradada em meio à pretensão organizacional das instituições sociais brasileiras e suas marcas simbólicas. Nesse sentido, esse processo de descompartimentação põe em xeque a tentativa moderna de separar para melhor controlar corpos e espaços urbanos, com o intuito de a eles impingir e fixar sentidos socialmente estabelecidos. Nessa mistura de materiais e fronteiras, ficaria 
explícito o desejo do personagem narrador de lançar-se profundamente na miséria para alcançar, eroticamente, um plano além do mundo simbólico, onde as fronteiras entre vida e morte, público e privado, sagrado e profano seriam cruzadas e se tornariam pouco nítidas, mas sem deixar de assumir um caráter de vida dada à experimentação. Nesse contexto, Eros e Thanatos se imbricam ao comporem o conflituoso jogo pulsional, contido no erotismo, que tenta transformar tanto a morte quanto a própria vida em deslocamento do ser rumo ao abismo do desconhecido, para além das categorizações usuais de identidade. Nesse processo, o corpo misturado às misérias é vivido em suas dimensões superficial e profunda ao elevar a potencialidade trágica da experiência erótica ao máximo, materializando, assim, esse desejo ambivalente de dissolver-se na degradação ao mesmo tempo em que a saboreia em êxtase. Dor e prazer se unem nesse momento, ilustrando a própria influência que Eros e Thanatos exercem na condução da libido do personagem. Nesse sentido, o prazer contido na dor poderia estar relacionado com a questão do sublime. Citado por Márcio SeligmannSilva, Edmund Burke afirma que:

Tudo que seja de algum modo capaz de incitar as idéias de dor e de perigo, isto é, tudo que seja de alguma maneira terrível ou relacionado ao terror constitui uma fonte do sublime, isto é, produz a mais forte emoção de que o espírito é capaz. Digo a mais forte emoção, porque estou convencido de que as idéias de dor são muito mais poderosas do que aquelas que provêm do prazer. O sublime é a manifestação de um máximo; é um abalo de muita intensidade que provoca deleite ou o "horror deleitoso" (1999: 125).

O conceito de sublime de Burke, elaborado em meados do século XVIII, parece dar conta das experiências-limite do narrador da narrativa de Noll que apresentam indícios dessa relação entre prazer e dor estabelecida pelo teórico, na medida em que o personagem converteria a dor contida no ato de degradar-se em prazer erótico, justamente porque o próprio risco presente nessas vivências torna-se condição fundamental para a ocorrência desse "horror deleitoso" de caráter trágico. Nesse sentido, sem perigo não haveria prazer para o narrador, assim como sem a dor o caráter trágico da experiência erótica estaria comprometido. Entretanto, como esse conceito de Burke estaria situado no contexto do século XVIII, não seria possível dizer que o narrador entra em contato com um sublime de acordo com os pressupostos do autor, e sim que suas interações corporais possuem 
uma relação dialética entre prazer e dor semelhante ao que preconiza o autor. Dessa forma, o conceito contemporâneo de abjeto proposto por Julia Kristeva seria mais pertinente para se analisar a passagem do texto de Noll, na medida em que "o abjeto representa a noite arcaica da relação pré-objetal; é a violência do luto de um 'objeto' sempre já perdido" (KRISTEVA apud SELIGMANN-SILVA, 1999: 133). Se, segundo Seligmann-Silva, o sublime remete ao espiritual (para cima), e o abjeto ao corporal (para baixo), ao tornar seu corpo miserável e passível de decomposição fonte de êxtases, o narrador uniria, em si, as experiências do sublime e do abjeto. Mesmo porque a busca erótica apresentada pelo personagem estaria intimamente relacionada com essa relação "pré-objetal" de vislumbre do informe, na tentativa de "resgatar" a condição já perdida do estado primevo de indiferenciação pré-subjetiva, em forma de plenitude erótica e completude no "outro".

Sendo assim, não haveria, em Noll, uma esvaziante perda de fronteiras, como no texto de Gutiérrez, e sim uma "miscelânea" significativa, que reforça as misérias e as mazelas como dignas de serem "provadas", sentidas, buscadas para além do próprio sistema cultural que as classifica. Nesse sentido, as degradações corporais e ambientais como componentes das interações dos personagens parecem indicar não só uma referência à arbitrariedade das marcas institucionais, mas também ao seu esgotamento, no sentido de se mostrarem incapazes de lidar com o caráter contraditório e imprevisível do próprio desejo de se estabelecer contatos com o "outro" e com si próprio sem imposições ou restrições prévias.

Como se viu, nas sociedades pós-modernas, comprova-se a falência da modernidade em determinar uma identidade estável para os indivíduos, os quais deveriam ter profissão, endereço e papel familiar definidos, ou seja, uma identidade estável e passível de controle pelas instituições sociais. Esse projeto mostrar-se-ia fracassado, pois o sujeito não mais se contentaria em se reduzir aos limites do estabelecido, manifestando, assim, as frustrações e angústias causadas pela repressão da razão moderna aos seus desejos. Dessa forma, o indivíduo pós-moderno seria, inegavelmente, portador de incongruências que a tradição cultural moderna não conceberia em sua pretensão de controle e estaticidade do mundo simbólico. Projetos inovadores, trabalhos artísticos ou mesmo desejo de evasão para um lugar indefinível poderiam expressar essas contradições. Denise Maurano (1999: 41) afirma que: 
Somente a arte consegue, segundo Freud, de uma maneira particular, conciliar os dois princípios. $\mathrm{O}$ artista originalmente se afasta da realidade e deixa livre em sua fantasia desejos eróticos e ambições com os quais cria novas realidades admitidas pelos demais homens que admiram as valiosas imagens criadas e idolatram o artista como herói, via pela qual se compensam da insatisfação a que se submetem.

Dessa maneira, a cultura seria resultado da "conciliação" do princípio de realidade e do princípio de prazer, canalizando, assim, a libido para a criação artística ou intelectual. Nesse movimento compensatório da repressão aos "instintos" primordiais, a linguagem surge como um instrumento de representação das realidades psíquica e social, expressando, nela própria, o sentido de busca erótica do indivíduo capaz de transgredir interditos e, ao mesmo tempo, materializar os embates pulsionais humanos responsáveis pelo advento da civilização. Esses impulsos tornam-se mais intensos na modernidade tardia, que não mais consegue represá-los nem reduzi-los à estaticidade do sedentarismo identitário e mesmo cultural, típicos da modernidade. Nesse processo, a própria cultura manifestaria sua dinamicidade renovadora diante das tendências esclerosantes do instituído. A respeito dessas necessidades de mudanças, Michel Maffesoli (2001: 41), discorrendo justamente sobre o nomadismo, afirma que:

Desarticulando o que está estabelecido quanto a coisas e gentes, o nomadismo é a expressão de um sonho imemorial que o embrutecimento do que está instituído, o cinismo econômico, a reificação social ou o conformismo intelectual jamais chegam a ocultar totalmente.

Nesse sentido, o sujeito pós-moderno não seria mais portador de uma identidade fixa e estável, e sim relacional, dinâmica e múltipla, mesmo porque a impermanência e fluidez da realidade das coisas já seriam condições inegáveis das sociedades contemporâneas.

O personagem narrador do texto de Noll apresenta uma "ânsia de infinito" ou de evasão que são levadas ao extremo, pois, como já foi dito anteriormente, não as canalizaria, plenamente, para o âmbito cultural, e sim para o próprio corpo e os espaços urbanos. Em suas inversões, o plano simbólico das instituições sociais não significaria "vida" a ser mantida, e sim "morte" a ser negada, na medida em que a manutenção da ordem tornarse-ia asfixiante, e o desejo de transgredi-la "revigorante", ainda que seja pelo viés de misérias e pelo risco trágico de nelas se diluir. Nesse contexto, as 
degradações corporais e ambientais são experimentadas pelo personagem narrador de modo tão intenso e visceral que perdem seu caráter negativo para se tornarem positivos instrumentos de uma experiência eroticamente trágica, no sentido de conterem uma "promessa" de mais vida, ao mesmo tempo em que haveria o risco de diluição na própria morte. Percebe-se, novamente, a presença do jogo pulsional entre Eros e Thanatos, que, em seu "(des)equilíbrio" de forças, leva o desejo aos extremos do corpo e do ser via erotismo, beirando a anomia. Nesse sentido, existiria uma transgressão de limites na narrativa de Noll capaz de ressignificar a realidade simbólica ao invertê-la permanentemente (devir), enquanto que, no texto de Gutiérrez, a miséria de corpos e espaços citadinos reforçaria, apenas, a ideia de decomposição do plano físico e simbólico expressa na própria ausência de desejo e de subversão de fronteiras. Na narrativa cubana, o instituído não representaria a "morte" por sua ação reguladora do movimento "errante", e sim por sua ausência esvaziante que expõe a deterioração da possibilidade de existência humana em forma de civilização. Nesse sentido, tanto a pulsão de vida quanto a de morte mostrar-se-iam enfraquecidas em nível de tensão criativa, já que os personagens Reynaldo e Magda apresentariam baixo teor de desejo primordial para ser direcionado rumo à transgressão erótica dos interditos. Sendo assim, a própria linguagem, na condição de representante do desejo oriundo do conflito entre os princípios de realidade e de prazer, responsável pela inserção cultural da vida em sociedade, estaria comprometida na narrativa, evidenciando, assim, não a primazia de Thanatos sobre Eros, mas uma desintegração de ambas as forças pulsionais. Devido ao baixo nível de intermediação cultural, a "libido" se transforma apenas em energia sexual animalizada nos personagens, restando a eles perambularem sem orientação enquanto seus corpos e os espaços urbanos se degradam. Não é à toa que, ao final da narrativa, a cidade de Havana é varrida por uma forte tormenta, seguida não só do desmoronamento de edificações velhas e dos corpos desgastados de Reynaldo e Magda, mas também da desintegração das marcas simbólicas institucionais que os acompanham e dão sentido à vida em sociedade.

Sobre a necessidade humana de errância, Maffesoli observa que "o andarilho, como o nome indica, serve de certa forma de má consciência. Ele violenta, por sua própria situação, a ordem estabelecida e lembra o valor da ação de pôr-se a caminho." (2001: 41-2). O personagem narrador e Afrodite, no texto de Noll, ilustram esse processo de se lançarem ao mundo, enfatizando a tragicidade desse movimento inerente à própria 
condição humana, na medida em que seria amplificada pelo caráter excessivamente corporal e miserável de suas andanças. Nesse sentido, ao explorar seus próprios limites e possibilidades, "o único roteiro é o corpo. O corpo." (NOLL, 1981: 34) O ato de perambular pelos espaços diversos da cidade, sem projetos definidos e planejamentos prévios, estaria íntima e "organicamente" relacionado ao movimento de caminhar pelo "corpo" urbano. Ao estender suas fronteiras corporais para os ambientes citadinos, misturando-os, os personagens parecem circular pela própria cidade como se fosse um "corpo" a ser experimentado de modo profundo, pois compartilham degradações, sujeiras e secreções materialmente tão impregnadas em suas existências que delas não mais se separariam. Assim, a troca frequente e intensa de parceiros sexuais em espaços diversos, bem como a sensibilidade corporal concentrada em sua materialidade erotizada, enuncia o corpo como referência e medida em seus percursos de andarilhos. A própria cidade assumiria dimensões corporais, na medida em que se tornaria extensão dos corpos dos personagens, mediados pela sujeira. Dessa maneira, os "corpos" e os espaços urbanos seriam ligados pela condição aventurosa do ato de perambular, já que o indefinido, inerente ao próprio "devir", se apresentaria diante deles para ser experimentado em seu caráter imprevisível e desconhecido. A falta de identificação definida e definitiva com espaços urbanos determinados, como moradia ou local de trabalho, seria reflexo do descompromisso dos personagens com as instituições sociais e suas marcas simbólicas. Ao não se subordinarem a essas demarcações, os andarilhos da narrativa nolliana as subverteriam via perambulações pela cidade, colocando em circulação não só seus corpos e ambientes citadinos, mas seus sentidos usuais, transgredidos em sua condição de significar a vida social. Nesse processo, os símbolos não deixariam de existir, mas seriam efetivamente transgredidos através das inversões redimensionadoras da realidade, transformados em "interditos" a serem superados em nome de uma revivificação erótica. Desestabilizados, os signos entrariam em movimento contínuo em forma de deslocamentos entre significante e significado, rompendo com a estabilidade de sistemas sociais fechados em si mesmos. Sendo assim, haveria rejeição da estabilidade do instituído, ao mesmo tempo em que a caoticidade do "devir" seria desejada, redimensionando, nessa dinâmica, a "ordenação" impressa em corpos e espaços da cidade. Seria nesse sentido que o erotismo impulsionaria o ato de perambular pela urbe, transgredindo limites. Essa maneira erotizada de encarar as misérias da vida pode ser observada, claramente, na passagem seguinte: 
Ela estava jogada agora num canto do terreno traseiro da Boate Night Fair, pernas abertas, os nervos genitais ainda latejantes, [...] minha cara também toda lambuzada, corri a mão pela cara e pelo corpo todo me lambuzando mais ainda, o sangue pelo corpo todo, você disse parece um índio todo pintado na frente do espelho, um índio pronto para o ritual da consagração, eu precisava daquele sangue $[\ldots]$.

Afrodite arreganhou os lábios da buceta com os dedos e eu só aí notei que ela estava menstruada. Eu gostava daquele sangue, imprimiria nele a minha sede que ficava vermelha, vermelha era a minha sede, o meu pau subia e nisso estava a minha dignidade, não a minha dignidade de macho ou qualquer coisa que significasse minha cidadania há tanto aviltada pela Cidade que me fora dada, não era macho nem fêmea nem cadela nem galo, eu era meu pau subindo, [...] enfio sim meu amor, enfio a mão na tua buceta, enfio a vida na tua buceta, se você precisar enfio a alma na tua buceta e te darei luz, é só você pedir que serei todo amor [...]. (1981: 25, 26-7).

O sangue menstrual, tido como interdito para o sexo e fonte de impurezas em algumas culturas, é exteriorizado e misturado ao corpo do narrador personagem como sendo algo desejável e vivificante, ao mesmo tempo em que a penetração do corpo de Afrodite seria muito mais que um simples ato sexual, pois assumiria um caráter passional de desejo pelo outro e pelo indefinível da "alma" ou da condição humana. O sangue, além de ser considerado como um fluido vital pertencente aos compartimentos internos do corpo, poderia expressar, na narrativa, o desejo ardente e visceral do narrador por Afrodite. Além disso, esse líquido orgânico poderia remeter ao calor do desejo erótico capaz de fundar a própria vida em seu aspecto primordial e iniciático. Seria como se os corpos do personagem narrador e de Afrodite, em suas profundidades e exterioridades, reunissem condições geradoras da própria vida, transgredindo, através do desejo erótico, a "cidadania há tanto aviltada pela Cidade". A imagem do "índio" na frente do espelho remeteria, também, a um momento em que o "nomadismo fundador" seria "consagrado", ou seja, inaugurado a partir do próprio corpo em seus elementos orgânicos tidos como vis, mas que, na passagem, tornaria a miserabilidade da vida profana do submundo carioca "sacralizada", ao resgatar um tipo de estado "selvagem" primordial, anterior às formatações da civilização ocidental. Segundo Maffesoli,

Há, de fato, em determinados momentos, alguma coisa que remete à pureza das iniciações. Uma espécie de beleza virginal rica de múltiplas possibilidades. 
A lembrança de uma juventude arquetípica em relação às coisas e o mundo. Trata-se, no caso, de um processo recorrente que, de um modo cíclico, reemerge na memória coletiva. Serve de anamnese àquilo que foi um ato fundador: de um amor, de um ideal, de um povo, de uma cultura, e por aí revigora a entidade em questão, redinamiza-a e lhe dá uma nova vida. (2001: 39).

Esse caráter revigorante do "nomadismo", em nível cultural, não ocorreria na narrativa, pois ficaria apenas no âmbito de uma potencialidade "dionisíaca" latente, capaz de desestabilizar o estabelecido, mas não de instituir uma nova ordem social, e sim apenas o trágico impulso erótico de pôr-se a caminho indefinidamente. Na passagem de Noll, o "interior" e o "exterior" dos corpos seriam subvertidos, pois o sangue menstrual sai de "dentro" de Afrodite em direção às mãos, rosto e demais partes expostas do corpo do personagem narrador, misturando-os material e simbolicamente. Os compartimentos público e privado de espaços da cidade são também invertidos ao se exibirem partes corporais íntimas em um ambiente aberto da boate. De qualquer forma, essas inversões parecem tornar os corpos demasiadamente "públicos" no sentido de tornarem explícitos seus processos de imersão no movimento erótico transgressor, exibindo não só seus corpos em profundidade, mas também as "entranhas" da sociedade, "remexidas" pela circulação dionisíaca de seus símbolos. Nesse processo, os corpos humanos e urbanos são apreendidos existencialmente pelo sujeito, resgatando, no instante da transgressão erótica, a plenitude ontológica do ser, há muito aviltada e esfacelada pelos interditos sociais.

Já na narrativa de Gutiérrez, Reynaldo mostra-se extremamente reduzido às necessidades fisiológicas de seu corpo, sem apresentar erotismo em suas interações sexuais ou espaciais, mesmo que, em alguns momentos, haja subversão de algumas normas socialmente instituídas:

- Ei, estou cagando! Onde é que eu posso ir cagar aqui?

- Nãonãonãonãonãonão.

- Nãonãonãonãonãonão o quê? Estou quase cagando, porra. Não escutou? Onde é que se caga?

- Até tocar a campainha. Quando tocar a campainha você pode ir.

$[\ldots]$

A linha de produção continuava soltando garrafas e caixas. Os outros não podiam parar para ajudar o sujeito no chão. Rey por pouco não cagava nas 
calças. Saiu correndo para um canto, atrás de umas caixas de cerveja, e cagou. Cagou muito bem. Ufa. Achou que tinha terminado. Não. Cagou mais um pouco. Pronto. Ahhh. Não tinha com que limpar. Com a mão. Limpou-se o melhor possível com os dedos, que limpou, por sua vez, no chão. Vestiu as calças e saiu. (2001: 133).

Reynaldo defeca em espaço não designado para isso, depois de ter negada a autorização para sair e satisfazer essas necessidades. O personagem transgride as normas sociais que gerem a fábrica de cerveja, pois esse espaço de trabalho é utilizado para a realização de um ato tido como íntimo e pessoal, ao mesmo tempo em que o local seria aberto ao trânsito de outras pessoas. Além disso, Rey desobedece à ordem dada para permanecer trabalhando, não se sujeitando ao comportamento determinado pelo "poder disciplinar" da fábrica, representado pelo funcionário superior e pela campainha. O adolescente, porém, é "conduzido" àquele local não por desconhecimento dos hábitos individuais e das marcas simbólicas dessas repartições espaciais, e sim pela vontade desesperada de se aliviar, não encontrando, assim, outra opção de conduta. De qualquer forma, as instâncias pública e privada parecem ser invertidas, pois, ainda que o adolescente tenha perguntado sobre autorização e local apropriado para satisfazer suas necessidades, ele as ignora e desrespeita. Essas inversões simbólicas do espaço seriam realizadas muito mais por questões fisiológicas do que eróticas propriamente ditas, ainda que existam, nessa passagem, as regras sociais determinadas e seus respectivos espaços organizados para a realização de certas práticas.

Para haver transgressão erótica, segundo Georges Bataille (2004), seriam necessárias as presenças do instituído como interdito e do desejo de subvertê-lo. Percebe-se a existência de ambos na narrativa de Noll. No texto de Gutiérrez, entretanto, as referências simbólicas seriam ignoradas por Rey na grande maioria de suas interações com outros corpos e espaços, além de se mostrarem já previamente enfraquecidas em suas demarcações devido ao próprio distanciamento das instituições cubanas em relação aos personagens vários e aos ambientes urbanos de Havana. Nesse sentido, não haveria muito que transgredir por Reynaldo e outros, pois a inexistência do desejo fundamental, aliada a regras sociais não muito nítidas em suas delimitações, resultaria em um contexto "deserotizado" e, portanto, pobre em caráter transgressivo. Se o poder público se mostra pouco presente em certos ambientes da cidade, os personagens ali situados tenderiam a realizar suas frequentes atividades sexuais de modo mais "disseminado" 
e em público. E já que eles não manifestam muita preocupação com os dispositivos coercitivos do Estado cubano, o caráter erótico e transgressivo das interações sexuais parece ser minimizado ou mesmo esvaziado, principalmente no caso de Reynaldo.

$\mathrm{Na}$ passagem acima, a falta de nitidez de contornos corporais e de referências espaciais, mediada pela sujeira e excrementos, parece revelar, em nível do enunciado, a lógica do andarilho: andar pelas ruas sem rumo seria análogo ao movimento de percorrer as extensões da única coisa que pensam possuir, ou seja, o próprio corpo. Entretanto, esse movimento não seria produzido, na narrativa de Gutiérrez, pela luta pulsional entre Eros e Thanatos para direcionar o desejo, como acontece em Noll, e sim pela inércia dos corpos andarilhos, psíquica e existencialmente passivos. De qualquer maneira, ao se experimentarem em locais e com parceiros diversos, no âmbito físico e superficial de seus corpos, seja através do sexo ou de violências múltiplas, os personagens percorrem as ruas como se fossem extensões de suas próprias corporeidades ou "componentes de si". A partir do momento em que se mostra impelido apenas pelas necessidades corporais, sem apresentar em suas ações qualquer planejamento prévio, objetivo definido ou transgressão erótica, Reynaldo não poderia ser considerado dono nem de seu próprio corpo. Nesse sentido, o fato de o adolescente se movimentar de modo "automatizado", por inércia e sem que sua subjetividade esvaziada interfira nesse processo, indicaria a falta de domínio e consciência de si, resultando em um processo de animalização só possível de se desenvolver, existencialmente, em um corpo "sem dono". Dessa maneira, com o corpo e a mente "desumanizados", o adolescente "prescindiria" de qualquer tipo de autonomia capaz de interferir em sua corporeidade, já que não teria disponibilidade de recursos eróticos nem tampouco culturais. Sendo assim, Reynaldo movimentar-se-ia muito mais por impulsos fisiológicos do que por pulsões, pois sua subjetividade já comprometida também se inseriria em seu processo de tanatomorfose, esvaziando-se tanto erótica quanto simbolicamente. Em seu percurso como andarilho, o corpo de Rey apenas expressaria, orgânica e materialmente, a degradação que está em sua estrutura psíquica, resultando em ruínas anatômicas que entram em consonância com as urbanas, fazendo referência, assim, a uma morte realmente nadificada, que remete a um vazio absoluto.

Assim como qualquer andarilho excluído socialmente de uma forma geral, os personagens das narrativas de Noll e de Gutiérrez não apresentam pontos de referência espaciais fixos ou permanentes, como moradia e local 
de trabalho. Não há, pois, "origem" nem "fim" definidos a serem alcançados em seus movimentos, e sim espaços a serem percorridos. Ainda que os personagens do texto de Noll perambulem via pulsões eróticas e os de Gutiérrez caminhem por impulsos restritos ao funcionamento meramente orgânico do corpo, em ambas as narrativas os andarilhos apresentam-se vinculados à extrema falta de inteireza e de fixação espacial, remetendo suas identidades ao não pertencimento a nenhum espaço específico e definitivo das respectivas cidades. De Certeau afirma que "caminhar é ter falta de lugar. É o processo indefinido de estar ausente e à procura de um próprio." (1994: 183) Porém, haveria uma diferença fundamental entre os textos cubano e brasileiro: os personagens de Noll estariam, realmente, "à procura de algo" na instância material da realidade, mas, ao mesmo tempo, "além" dela, enquanto os de Gutiérrez se encontrariam, efetivamente, "ausentes" desse processo pelo caráter esvaziado de sua "procura", movida somente pela fome ou sexo. Dessa forma, não há, em ambas as narrativas, locais específicos a funcionarem como referência espacial e foco de identificação permanente, assim como os corpos não se restringem às interações específicas e fixas entre eles próprios. As corporeidades, então, seriam "pulverizadas" ao se deslocarem muito menos em busca de uma estabilidade de identificação com corpos e espaços do que em direção a um paulatino processo de "desindividualização". Entretanto, no texto de Noll, $\mathrm{o}$ ato de perambular pelas ruas da cidade do Rio de Janeiro apresentaria um alto grau de tragicidade devido ao arriscado processo realizado pelos personagens de se perderem na "(in)definida" e imprevisível busca de si no "outro", enquanto os andarilhos "habaneros" não assumiriam qualquer risco em seus percursos previsíveis ao se mostrarem já condenados a uma desintegração paulatina e absoluta. Seria nesse sentido que a "morte" é preenchida com "vida" erotizada no texto brasileiro, onde Eros e Thanatos convergem suas forças pulsionais para a tragicidade do desejo erótico, beirando o intangível da condição humana. De modo diverso, a "morte" seria esvaziada de signos e desejos no romance cubano, o qual tornaria evidente não só a decomposição pura e simples dos corpos, mas o seu caráter desumanizado e, portanto, culturalmente inadmissível.

Jurandir Freire Costa, em seu artigo intitulado "Playdoier pelos irmãos", considerando problemático o fato de a cultura deixar de ser o campo de investimento criativo dos indivíduos enquanto sujeitos ativos de seus próprios processos, afirma que "a verdadeira ameaça [...] está no desinvestimento da cultura, em seu abandono como espaço privilegiado da 
expressão subjetiva" (2000: 24). Nesse sentido, os personagens de Gutiérrez parecem estar inseridos em um extremo processo de "desinvestimento cultural", na medida em que não apresentam desejos, planos ou projetos de vida, além de fazerem pouco uso da linguagem e nenhum da reflexão crítica. Dessa forma, os indivíduos se "desinvestem" da cultura ao se misturarem ao lixo, sofrendo degradações diversas. Ivete Walty e Maria Zilda Cury, ao mencionarem esse conceito de Jurandir Freire Costa, afirmam que, "segundo o autor, mais que sobre o recalque do sexual, como assinalado por Freud, a sociedade erige-se sobre a possibilidade de criação que dá origem à cultura" (2004: 59). Em caminho inverso, observa-se, no texto de Gutiérrez, o desmoronamento dos corpos e do próprio sistema e, consequentemente, o esfacelamento da cultura e da identidade. Mutilados, inclusive, no processo erótico de investimento no "outro", em si próprios e na cultura, restam aos personagens apenas o corpo e o sexo como único referencial e medida de identidade. Nessas condições, os personagens perambulam pelos espaços urbanos gerenciados apenas pelos seus corpos e seus impulsos mais instintivos, já que se encontram comprometidos enquanto sujeitos culturais.

$\mathrm{Na}$ narrativa de Noll, esse processo de abandono da cultura como espaço criativo e de construção da própria subjetividade também existe, mas com algumas diferenças, pois se percebe que os personagens também perambulam pelos espaços degradados das ruas cariocas, mas ainda se preocupam, até certo nível, com suas identidades humanas, mesmo que não se envolvam com qualquer projeto de cunho cultural e pessoal. Se o narrador e o mendigo, na passagem seguinte, apenas perambulam, eles ainda falam inserindo-se, de alguma forma, no mundo da cultura:

Não seu doutor, fico aqui deitado falando sozinho porque o éter que eu gostava de cheirar não arrumei mais, cheirava meu éter e parecia que tudo parava, depois um sono maior que em mim caía, caía mas não sonhava, sabe?, o que fazia mesmo era viver ao contrário, não, não era como morto não e sabe por que?, porque eu continuava falando sozinho, vinham umas idéias quase parando mas eram idéias sim senhor, espichava uma palavra até não poder mais pra que ela não morresse em vida sabe? (1981: 20).

Ao afirmar "viver ao contrário", o indigente situa-se como socialmente excluído, mas evidencia um fio de inserção no mundo da cultura. Ironicamente, ele faz uso da palavra muito mais no sentido de transgressão dela própria do que de uma elaboração culturalmente instituinte. Aliás, a 
tônica do romance parece ser bem esta: um mergulho profundo nas misérias e mazelas humanas no sentido de vivenciá-las visceral e eroticamente em suas entranhas, ao invés de querer sair delas ou vencê-las. Se no texto de Gutiérrez o processo de desinvestimento cultural se manifesta de forma extremada, inclusive em nível de linguagem dos personagens, na narrativa de Noll isso reside mais na condição de excluídos socialmente dos personagens que no exagero, no "transbordamento" e na circulação de signos, os quais tentam expressar o inominável da experiência erótica em nível do simbólico.

Seja por esvaziamento do desejo e da linguagem no texto de Gutiérrez, ou por transgressões eróticas que beiram o indefinido na narrativa de Noll, as feridas infeccionadas e as fraturas expostas dos corpos dos andarilhos de ambos os romances estendem as suas fronteiras e contaminam o "corpo" das instituições sociais brasileiras e cubanas, ficando a própria cultura que as criaram e o conceito de civilização, irreversivelmente, problematizados.

Os andarilhos e as cidades expõem as contaminações não só de instâncias físicas, mas principalmente simbólicas dos corpos humanos e urbanos, os quais se tornam "públicos" pelo viés das próprias narrativas literárias. Ao mostrarem os personagens e os espaços citadinos em seus desgastes diversos, assim como a ligação entre o processo de desinvestimento cultural e a crise das instituições sociais, como a família, o presídio, o hospital, a Igreja e o Estado, ambas as narrativas tornam "explicitamente" públicos, via linguagem, esses corpos diversos e a ilusória tentativa de domesticar os seres humanos através do controle repressivo da sexualidade, pois, no processo mesmo de criação da cultura e da civilização residiria sua ruína em potencial, já que estruturada no conflituoso e frágil equilíbrio entre as pulsões responsáveis pela ambivalência do desejo de viver e, simultaneamente, de morrer.

\section{REFERÊNCIAS BIBLIOGRÁFICAS}

BATAILLE, Georges. O erotismo. Trad. Cláudia Fares. São Paulo: Editora Arx, 2004.

COSTA, Jurandir Freire. Playdoier pelos irmãos. In: KHEL, Maria Rita (Org.). Função fraterna. Rio de Janeiro: Relume-Dumará, 2000. p. 7-30.

CURY, Maria Zilda; WALTY, Ivete Lara Camargos. In memoriam: escrita e lixo. Cerrados: Revista do Programa de Pós-graduação em Literatura, n. 17 (Literatura e Globalização), p. 55-60, 2004. 
DE CERTEAU, Michel. A invenção do cotidiano: artes de fazer. Trad. Ephraim Ferreira Alves. Petrópolis: Vozes, 1994. v. 1.

FREUD, Sigmund. O mal-estar na civilização. In: FREUD, Sigmund. Edição Standard Brasileira das Obras Psicológicas Completas de Sigmund Freud. Trad. Christiano Monteiro Oiticica. Rio de Janeiro: Imago Editora, 1974. v. 21.

GUTIERREZ, Pedro Juan. O rei de Havana. São Paulo: Companhia das Letras, 2001.

HABERMAS, Jurgen. Mudança estrutural da esfera pública. Trad. Flávio R. Kothe. Rio de Janeiro: Tempo Brasileiro, 2003.

KRISTEVA, Julia. Poderes de la perversión. Ensayo sobre Louis F. Céline. México: Catálagos Editora, 1988.

MAFFESOLI, Michel. Sobre o nomadismo. Vagabundagens pósmodernas. Trad. Marcos de Castro. Rio de Janeiro; São Paulo: Record, 2001.

MARX, Karl. Para a crítica da economia política. In: OS PENSADORES. Trad. Edgard Malagodi. São Paulo: Editora Nova Cultural, 2000.

MAURANO, Denise. Nau do desejo. O percurso da ética de Freud a Lacan. Rio de Janeiro: Relume Dumará, 1999.

NOLL, João Gilberto. A fúria do corpo. Rio de Janeiro: Record, 1981.

RODRIGUES, José Carlos. Tabu do corpo. Rio de Janeiro: Editora Fiocruz, 2006.

RODRIGUES, José Carlos. Tabu da morte. Rio de janeiro: Editora Fiocruz, 2006.

SELIGMANN-SILVA, Márcio. Do delicioso horror sublime ao abjeto e à escritura do corpo. In: ANDRADE, Ana Luíza et al. (Org.). Leituras do ciclo. Florianópolis: ABRALIC/ Chapecó/ Grifos, 1999. p. 123-136.

SENNETT, Richard. Carne e pedra. Trad. Marcos Aarão Reis. Rio de Janeiro: Record, 1997. 